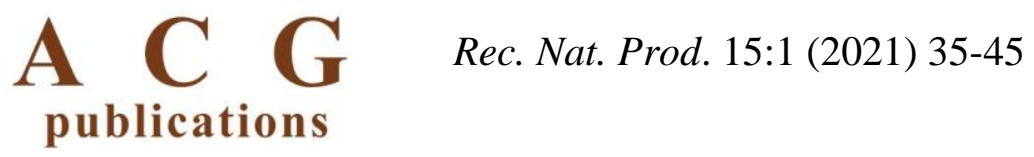

\title{
Composition and Antimicrobial Activity of Myrica gale L. Leaf and Flower Essential Oils and Hydrolates
}

\author{
Karolina Wawrzyńczak $\oplus^{1 *}$, Beata Sadowska $\oplus^{2}$, \\ Marzena Więckowska-Szakiel $\oplus^{2}$ and Danuta Kalemba $\oplus^{1}$
}

\author{
${ }^{1}$ Institute of Natural Products and Cosmetics, Faculty of Biotechnology and Food Sciences, Lodz \\ University of Technology, 90-924 Lodz, Poland \\ ${ }^{2}$ Department of Immunology and Infectious Biology, Institute of Microbiology, Biotechnology and \\ Immunology, Faculty of Biology and Environmental Protection, University of Lodz, 90-237 Lodz,
}

\author{
Poland
}

(Received April 28, 2020; Revised July 07, 2020; Accepted July 08, 2020)

\begin{abstract}
Myrica gale L. (sweet gale) leaves and flowers were subjected to industrial steam distillation in order to obtain essential oil and hydrolate. Obtained products were investigated to determine their chemical composition and antimicrobial activity. The main components found in both leaf and flower essential oils were monoterpene hydrocarbons: $\alpha$-pinene $(12.3,23.5 . \%), p$-cymene $(12.8,4.9 \%)$, and limonene $(11.0,5.6 \%)$, respectively. While oxygenated monoterpenes: 1,8-cineole (28.6, 44.2\%), terpinen-4-ol (14.3, 13.4\%), and $\alpha$ terpineol $(15.6,11.3 \%)$ were dominant compounds in leaf and flower hydrolates. Essential oil and hydrolate from $M$. gale leaves exhibited antimicrobial activity against obligatory and opportunistic bacterial pathogens such as Staphylococcus aureus, Escherichia coli, and Enterococcus faecalis. Interestingly, the leaf essential oil, but not the hydrolate, was also active against Candida albicans and Candida glabrata - yeast included in human skin and mucous membrane microbiota and simultaneously important fungal pathogens.
\end{abstract}

Keywords: Sweet gale; monoterpenes; antimicrobial activity. (C) 2020 ACG Publications. All rights reserved.

\section{Introduction}

Myrica gale L. known as myrique baumier or sweet gale is a species of aromatic shrub from the family of Myriaceae. M. gale is found world-wide in the northern hemisphere. It is widely spread at higher latitudes. In Europe it is distributed in the east-central Highlands [1]. In Poland sweet gale is the only representative of the Myriaceae family and occurs naturally only in the narrow coastal strip of Baltic Sea [2]. Myrique baumier is a protected plant, however, it can be successfully cultivated.

Research concerning essential oil composition of $M$. gale from different origins revealed considerable differences as it was presented previously by Svoboda et al. [3] and recently by Wawrzyńczak et al. [4]. Essential oils of the plants collected from most of the locations were rich in $\alpha$ pinene (12.2-38.9\%), apart from those originating from Canada and Japan ( $\alpha$-pinene content 2.2 and $1.9 \%$, respectively) [3-7]. Leaf essential oil from Canadian myrique baumier was the only one in which considerable amount of myrcene (11.3\%) was identified [5]. This compound was also present in essential oils from the plants of Polish origin, up to $2.2 \%$ in the case of senescent leaves [4]. Germacrone, the compound that possesses some valuable properties, including antitumor effect

\footnotetext{
*Corresponding author: E-mail: karolina.wawrzynczak@edu.p.lodz.pl
} 
against human hepatoma and antimicrobial activity against early stage of influenza [8-9], was present at high quantities in leaf and fruit essential oils of the plants from France (25.1, 14.2\%, respectively) [7] and in flower essential oil of the plants from Poland - up to 8.9\% [4]. Essential oils obtained during different development stages of the plants were also assessed. It was proven that M. gale senescent leaves were more valuable source of essential oils than matured leaves [3-4].

In present study a composition of $M$. gale leaf and flower essential oils and hydrolates produced in an industrial scale and their antimicrobial activity were assessed. The changes in hydrolate volatiles' content and composition during distillation time were also indicated.

\section{Materials and Methods}

\subsection{Collection of Plant Material}

Myrica gale male flowers $(4.5 \mathrm{~kg})$ and leaves $(11 \mathrm{~kg})$ were collected from organic farm in Połczyno, Poland $\left(54^{\circ} 42^{\prime} \mathrm{N} 18^{\circ} 20^{\prime} \mathrm{E}\right)$ in June and September 2015 , respectively. The plant material identification was done by Dr. Jeremi Kołodziejek from Department of Geobotany and Plant Ecology, University of Lodz and a voucher specimen No 157386 is deposited at the Herbarium Universitatis Lodziensis LOD- Poloniae.

\subsection{Steam Distillation of Essential Oils and Hydrolates}

Essential oils and hydrolates were obtained by industrial steam distillation using InnotecTetekov TWE 250-2000 VA apparatus (distillation cylinder $2 \mathrm{~m} \mathrm{x} 0.25 \mathrm{~m}$, volume $98 \mathrm{l}$; working pressure 0.3 bar; steam quantity $12 \mathrm{~kg} / \mathrm{h}$, distillate quantity $200 \mathrm{~mL} / \mathrm{min}$.). Fresh flowers $(4 \mathrm{~kg})$ and leaves $(10.5 \mathrm{~kg})$ were steam distilled for $90 \mathrm{~min}$., which is a routine time indicated by the manufacturer in respect to the process profitability. The hydrolates were collected in $4 \mathrm{~L}$ containers. Four hydrolate fractions were obtained from the flowers and five from the leaves of M. gale. Representative total hydrolates were prepared by mixing $500 \mathrm{~mL}$ of all respective fractions, separately for the flower and leaf hydrolates. After the distillation neat essential oils were separated in the Florentine-type flask receiver. Essential oils were dried over magnesium sulfate.

\subsection{Isolation of Volatile Compounds from Hydrolate}

Volatile constituents of hydrolates fractions and total hydrolates were extracted with diethyl ether pure p.a. (CHEMPUR, Piekary Slaskie, Poland), previously rectified. Samples, $500 \mathrm{~mL}$ each, were salted-out with $180 \mathrm{~g}$ of sodium chloride prior to extraction, in order to reduce solubility of volatile compounds in water. Four portions $100 \mathrm{~mL}$ each of diethyl ether were used as an extractant. Combined extracts were dried over anhydrous magnesium sulfate and filtered. The solvent was removed using rotary evaporator at $40^{\circ} \mathrm{C}$. The remaining mixture of volatile constituents of hydrolates was weighed and the content of volatiles was reported as $\mathrm{mg} / \mathrm{L}$. Each extraction was repeated twice.

\subsection{GC-FID-MS Analysis and Identification of the Components}

Volatile compounds isolated from hydrolate as well as essential oil were analyzed by gas chromatography coupled with mass spectrometry (GC-FID-MS) [10]. Apparatus: Trace GC Ultra gas chromatograph coupled with DSQ II mass spectrometer (Thermo Electron Corporation). A simultaneous GC-FID and MS analysis was performed using MS-FID splitter (SGE, Analytical Science, Austin, TX, USA). Operating conditions: nonpolar capillary column Rtx-1ms (60 m x 0.25 $\mathrm{mm}, 0.25 \mu \mathrm{m}$ film thickness), programmed temperature: 50 (3 minutes) $-300^{\circ} \mathrm{C}, 4^{\circ} \mathrm{C} / \mathrm{min}$., injector (SSL) temperature $280^{\circ} \mathrm{C}$, detector (FID) temperature $300^{\circ} \mathrm{C}$, transfer line temperature $250^{\circ} \mathrm{C}$, carrier gas - helium, flow with constant pressure $200 \mathrm{kPa}$, split ratio 1:20. The mass spectrometer parameters: ion source temperature $200^{\circ} \mathrm{C}$, ionization energy $70 \mathrm{eV}$ (EI), scan mode: full scan, mass range 33-420. Identification of the components was based on a comparison of their mass spectra and relative retention indices with data stored in computer libraries NIST 98.1, Wiley 8th Ed. and MassFinder 4.1 
as well as literature [11]. Retention indices (RI, apolar column) were determined with relation to a homologous series of alkanes (C8-C26) under the same conditions with linear interpolation. The percentages of constituents were computed from the GC peak area without using a correction factor.

\subsection{Antimicrobial Activity Assessment}

Staphylococcus aureus ATCC 29213 (reference strain, MSSA - methicillin susceptible S. aureus), S. aureus H9 (clinical strain, MRSA - methicillin resistant S. aureus), Enterococcus faecalis ATCC 29212, Escherichia coli NCTC 8196, Pseudomonas aeruginosa ATCC 15442, Candida albicans ATCC 10231, and Candida glabarata ATCC 90030 were used in the study. Antimicrobial activity of $M$. gale leaf essential oil ( $\left(\mathrm{EO}_{\text {leaf }}\right)$ and hydrolate $\left(\mathrm{H}_{\text {leaf }}\right)$ were tested using microdilution method in broth to determine the minimal inhibitory concentration (MIC), followed by the culture on solid media to determine the minimal bactericidal concentration (MBC) or minimal fungicidal concentration (MFC). Microbial suspensions at the density of $5 \times 10^{5} \mathrm{CFU} / \mathrm{mL}$ in Mueller-Hinton Broth (for bacteria; Graso Biotech, Poland) or RPMI-1640 with 1\% L-glutamine (for yeast; Sigma, Germany) were exposed on $M$. gale leaf essential oil at the final concentration range of $0.097-1.56 \%$ $(\mathrm{v} / \mathrm{v})$ or the hydrolate at the final concentration range of $6.5-75 \%(\mathrm{v} / \mathrm{v})$ for $24 \mathrm{~h}$ at $37^{\circ} \mathrm{C}$ (bacteria) or $48 \mathrm{~h}$ at $35^{\circ} \mathrm{C}$ (yeast). Microbial suspensions at the same density $\left(5 \times 10^{5} \mathrm{CFU} / \mathrm{mL}\right)$ in appropriate media alone (Mueller-Hinton Broth for bacteria or RPMI-1640 with $1 \%$ L-glutamine for yeast) culture at the same conditions served as positive control. Visual and densitometric method (assessment of microbial growth based on the changes in absorbance of samples at $\lambda=600 \mathrm{~nm}$ ) was used to determine MIC values. MIC was defined as the lowest concentration of tested preparation inhibiting bacterial/fungal growth compared to the appropriate positive control. MBC/MFC of the preparations means the lowest concentration killing $99.9 \%$ of bacteria or yeast after subculturing $10 \mu \mathrm{L}$ of samples on Tryptic-soy agar (TSA; BTL, Poland; for bacteria) or Sabouraud's dextrose agar (SDA; BTL, Poland; for fungi) and further incubation for $24 \mathrm{~h}$ at $35-37^{\circ} \mathrm{C}$. Two experiments for each sample and each microbial strain were performed.

\section{Results and Discussion}

\subsection{Essential Oils and Hydrolates Composition}

Fresh leaves of $M$. gale $(10.5 \mathrm{~kg})$ yielded $4.2 \mathrm{~mL}(0.04 \%)$ of essential oil and five fractions 4 $\mathrm{L}$ each of hydrolate $(20 \mathrm{~L})$. From $4 \mathrm{~kg}$ of fresh flowers $25 \mathrm{~mL}$ of essential oil $(0.62 \%)$ and four fractions $(4 \mathrm{~L}$ each) of hydrolate were obtained $(16 \mathrm{~L})$. M. gale leaves and flowers both yielded pale green essential oil with fresh, green, herbal smell. Hydrolates were transparent liquids with characteristic smell resembling the essential oil smell. Yield of laboratory hydrodistilled essential oil of $M$. gale leaves varies between collection locations and development stage of the plant material in the range from $0.13 \%$ [3] to $0.55 \%$ [6]. The highest measured flower essential oil yield was $1.46 \%$ from the plant cultivated in Finland [3]. Laboratory distillation of dried leaves and flowers from the same origin as in the research presented here yielded $0.16 \%$ and $1.23 \%$ essential oils, respectively [4]. Usually the yield of essential oil in industrial steam distillation is lower than that observed in laboratory hydrodistillation.

The content of volatile compounds in hydrolates was assessed by extraction of salted hydrolate samples with diethyl ether. Different solvents were previously used for volatiles extraction from hydrolates, dichloromethane [12,13], hexane [14], pentane [15], and diethyl ether [10, 16,17] being the most common. Diethyl ether was chosen according to literature data as well as our previous experiences. 
Table 1. Composition of Myrica gale essential oils and hydrolate volatiles obtained from leaves and flowers in industrial steam distillation

\begin{tabular}{|c|c|c|c|c|c|c|c|}
\hline No & Compound & $\mathbf{R} \mathbf{I}_{\exp }$ & $\mathbf{R} \mathbf{I}_{\text {lit }}$ & $\begin{array}{c}\mathbf{E O}_{\text {leaf }} \\
{[\%]}\end{array}$ & $\begin{array}{c}\mathbf{E O}_{\text {flower }} \\
{[\%]}\end{array}$ & $\begin{array}{l}\mathbf{H}_{\text {leaf }} \\
{[\%]}\end{array}$ & $\begin{array}{c}\mathbf{H}_{\text {flower }} \\
{[\%]}\end{array}$ \\
\hline 1 & Hex-3-en-1-ol & 838 & 838 & - & - & 1.1 & - \\
\hline 2 & Octane & 800 & 800 & - & 0.1 & - & - \\
\hline 3 & Tricyclene & 921 & 927 & - & 0.2 & - & - \\
\hline 4 & $\alpha$-Thujene & 927 & 932 & 0.1 & 0.1 & - & 0.3 \\
\hline 5 & Benzaldehyde & 929 & 935 & - & - & 0.6 & - \\
\hline 6 & a-Pinene & 933 & 936 & 12.3 & 23.5 & - & - \\
\hline 7 & Camphene & 945 & 950 & 0.5 & 0.9 & - & - \\
\hline 8 & $\beta$-Pinene & 971 & 978 & 2.1 & 2.3 & - & - \\
\hline 9 & Myrcene & 984 & 987 & 0.5 & 1.2 & - & - \\
\hline 10 & $\alpha$-Phellandrene & 996 & 1002 & - & 3.2 & - & - \\
\hline 11 & 3-Carene & 1005 & 1010 & 0.1 & - & - & - \\
\hline 12 & $\alpha$-Terpinene & 1008 & 1013 & - & 0.4 & - & - \\
\hline 13 & Benzyl alcohol & 1010 & 1006 & - & - & 0.8 & - \\
\hline 14 & $p$-Cymene & 1013 & 1015 & 12.8 & 4.9 & - & 0.2 \\
\hline 15 & 1,8-Cineole & 1021 & 1024 & 2.2 & 8.0 & 28.6 & 44.2 \\
\hline 16 & Limonene & 1023 & 1025 & 11.0 & 5.6 & - & - \\
\hline 17 & (Z)- $\beta$-Ocimene & 1028 & 1029 & - & 0.9 & - & - \\
\hline 18 & 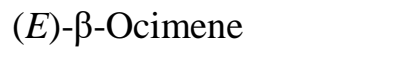 & 1040 & 1041 & - & 0.2 & - & - \\
\hline 19 & $\gamma$-Terpinene & 1050 & 1051 & - & 1.1 & - & - \\
\hline 20 & trans-Linalool oxide (f) & 1058 & 1058 & - & - & 0.1 & - \\
\hline 21 & cis-Linalool oxide (f) & 1072 & 1072 & - & - & $\mathrm{t}$ & - \\
\hline 22 & Nonanal & 1076 & 1076 & - & 0.4 & - & - \\
\hline 23 & Terpinolene & 1081 & 1082 & - & 0.4 & - & - \\
\hline 24 & Linalool & 1086 & 1086 & - & - & 1.6 & 1.1 \\
\hline 25 & $\alpha$-Fenchol & 1102 & 1099 & - & 0.1 & - & 0.9 \\
\hline 26 & $\alpha$-Campholenal & 1104 & 1105 & - & - & $\mathrm{t}$ & - \\
\hline 27 & cis-p-Menth-2-en-1-ol & 1111 & 1108 & - & - & 0.9 & 1.1 \\
\hline 28 & trans-p-Menth-2-en-1-ol & 1123 & 1116 & - & $\mathrm{t}$ & 1.0 & 1.1 \\
\hline 29 & cis-Verbenol & 1133 & 1132 & - & - & 0.1 & 0.1 \\
\hline 31 & Camphene hydrate & 1135 & 1143 & - & - & 0.4 & 0.7 \\
\hline 32 & $\delta$-Terpineol* & 1150 & 1155 & - & - & 1.6 & - \\
\hline 32 & Borneol* & 1151 & 1150 & - & 0.2 & 1.3 & 3.3 \\
\hline 33 & Terpinen-4-ol & 1166 & 1164 & - & 0.4 & 14.3 & 13.4 \\
\hline 34 & $\alpha$-Terpineol & 1172 & 1176 & - & 0.2 & 15.6 & 11.3 \\
\hline 35 & cis-Piperitol & 1183 & 1181 & - & - & 0.3 & 0.1 \\
\hline 36 & trans-Piperitol & 1192 & 1193 & - & $\mathrm{t}$ & 0.3 & - \\
\hline 37 & $\beta$-Cyclocitral & 1197 & 1195 & - & - & 0.1 & - \\
\hline 38 & $2 \alpha$-Hydroxy-1,8-cineole & 1120 & 1196 & - & - & 0.7 & 0.4 \\
\hline 39 & Benzylacetone & 1210 & 1207 & - & - & 1.6 & - \\
\hline 40 & Citronellol & 1212 & 1213 & - & - & 1.7 & - \\
\hline 41 & cis-Carveol & 1216 & 1210 & - & - & 0.4 & - \\
\hline 42 & Carvotanacetone & 1222 & 1220 & - & - & 0.1 & - \\
\hline
\end{tabular}


Table 1 continued..

\begin{tabular}{|c|c|c|c|c|c|c|c|}
\hline 43 & Piperitone & 1228 & 1226 & - & - & 0.2 & - \\
\hline 44 & Nonanoic acid & 1260 & 1263 & - & - & 0.1 & - \\
\hline 45 & Bornyl acetate & 1273 & 1270 & 1.0 & 0.8 & 0.2 & 0.3 \\
\hline 46 & Carvacrol & 1281 & 1278 & - & - & 0.4 & - \\
\hline 47 & Terpinen-4-yl acetate & 1285 & 1289 & - & 0.2 & - & - \\
\hline 48 & $\alpha$-Terpinyl acetate & 1336 & 1335 & 2.9 & 4.0 & 0.3 & 1.0 \\
\hline 49 & (E)-Methyl cinnamate & 1354 & 1354 & - & - & 0.2 & - \\
\hline 50 & Geranyl acetate & 1363 & 1362 & 0.1 & 0.4 & - & 0.1 \\
\hline 51 & Benzyl isovalerate & 1370 & 1370 & - & - & 0.1 & - \\
\hline 52 & $\alpha$-Ylangene & 1377 & 1376 & - & 0.1 & - & - \\
\hline 53 & $\alpha$-Copaene & 1380 & 1379 & 1.2 & 0.4 & - & - \\
\hline 54 & $\beta$-Elemene & 1391 & 1389 & 0.1 & - & - & - \\
\hline 55 & $\alpha$-Gurjunene & 1410 & 1413 & - & 0.1 & - & - \\
\hline 56 & (E)- $\beta$-Caryophyllene & 1422 & 1421 & 0.5 & 0.9 & - & - \\
\hline 57 & $\gamma$-Elemene & 1431 & 1429 & 2.0 & 0.5 & - & - \\
\hline 58 & $\alpha$-Humulene & 1454 & 1455 & 0.2 & $\mathrm{t}$ & - & - \\
\hline 59 & 7aH,10bH-Cadina-1(6),4-diene & 1469 & 1472 & - & 0.2 & - & - \\
\hline 60 & $\gamma$-Muurolene & 1474 & 1474 & 0.5 & - & - & - \\
\hline 61 & cis-Eudesma-6,11-diene & 1480 & 1484 & 0.2 & 0.3 & - & - \\
\hline 62 & $\beta$-Selinene & 1486 & 1486 & 1.3 & 0.4 & - & - \\
\hline 63 & $\alpha$-Selinene & 1499 & 1494 & 0.3 & 0.6 & - & - \\
\hline 64 & trans-Calamenene & 1513 & 1517 & 1.6 & 0.4 & - & 0.2 \\
\hline 65 & $\delta$-Cadinene & 1515 & 1520 & - & 3.4 & - & 0.3 \\
\hline 66 & $\beta$-Cadinene & 1517 & 1526 & 1.7 & 0.1 & - & 0.2 \\
\hline 67 & Selina-4(15),7(11)-diene & 1534 & 1534 & 9.8 & 8.1 & - & 1.3 \\
\hline 68 & Selina-3,7(11)-diene & 1543 & 1542 & 4.4 & 7.9 & - & 1.2 \\
\hline 69 & $(E)$-Nerolidol & 1551 & 1553 & 6.3 & 2.1 & 1.0 & 1.1 \\
\hline 70 & Spathulenol & 1575 & 1572 & 1.6 & - & 0.1 & - \\
\hline 71 & Caryophyllene oxide & 1578 & 1578 & 1.2 & - & - & $\mathrm{t}$ \\
\hline 72 & $\beta$-Elemenone & 1586 & 1589 & 1.7 & 4.5 & 1.4 & 3.7 \\
\hline 73 & Isospathulenol & 1614 & 1625 & - & - & 2.5 & 1.5 \\
\hline 74 & 1-epi-Cubenol & 1619 & 1623 & 0.7 & 0.3 & 0.6 & 0.4 \\
\hline 75 & Germacrone* & 1678 & 1684 & 0.8 & 3.6 & 1.7 & 3.0 \\
\hline 76 & Eudesm-7(11)-en-4 $\alpha$-ol* & 1681 & 1676 & 0.7 & 0.7 & 0.7 & 0.9 \\
\hline 77 & Heptadecane & 1700 & 1700 & - & - & - & 0.2 \\
\hline 78 & Benzyl benzoate & 1728 & 1730 & 0.1 & - & 0.3 & - \\
\hline & Total identified & & & 82.5 & 94.3 & 83.0 & 93.6 \\
\hline & Monoterpene hydrocarbons & & & 39.4 & 44.5 & - & 0.5 \\
\hline & Oxygenated monoterpenes & & & 6.2 & 14.7 & 71.9 & 79.1 \\
\hline & Sesquiterpene hydrocarbons & & & 23.8 & 23.4 & - & 3.2 \\
\hline & Oxygenated sesquiterpenes & & & 13.0 & 11.2 & 8.0 & 10.6 \\
\hline & Others & & & 0.1 & 0.5 & 3.1 & 0.2 \\
\hline
\end{tabular}


Composition of $M$. gale essential oils and volatiles extracted from representative total leaf and flower hydrolates' is presented in the Table 1 . The content of volatile compounds and percentage composition of the main constituents of hydrolate fractions and total hydrolate is presented in Table 2 and Table 3 for leaf and flower hydrolate, respectively. Summarizing, 33 compounds were identified in leaf essential oil and 47 in flower essential oil. While 38 and 30 different compounds were found in leaf and flower hydrolate, respectively.

The essential oils composition was to broad extent consistent with a composition of previously investigated essential oils from the same origin. Some differences of quantitative nature occurred [4]. The main constituents of the industrial M. gale leaf and flower essential oil were monoterpene and sesquiterpene hydrocarbons that constituted $63.2 \%$ and $67.9 \%$, respectively. The major compound were $\alpha$-pinene $(12.3,23.5 \%$, respectively), $p$-cymene $(12.8,4.9 \%)$, limonene $(11.0,5.6 \%)$, selina4(15),7(11)-diene $(9.8,8.1 \%)$, and selina-3,7(11)-diene (4.4, 7.9\%). Most of the major compounds have been previously identified [3,4,6-8] with some differences between the essential oils isolated from the plants originating from different locations. 1,8-Cineole that was present in large quantities in the leaf and flower essential oils obtained in laboratory hydrodistillation of the same materials (18.1, $20.9 \%$ ) [4] was found in smaller amounts in both industrial essential oils and amounted to $2.2 \%$ and $8.0 \%$, respectively. According to previous reports the contents of sesquiterpene ketones $\beta$-elemenone and germacrone were in the broad range of $0-25.1 \%$. In this research $\beta$-elemenone and germacrone percentages were higher in flower essential oil (4.5 and 3.6\%) than in leaf essential oil (1.7 and $0.8 \%)$.

Volatile organic compounds of M. gale leaves and flowers hydrolates were rich with oxygenated monoterpenes (71.9 and $79.1 \%$ of all compounds, respectively). 1,8-Cineole (28.6, $44.2 \%)$, terpinen-4-ol $(14.3,13.4 \%)$, and $\alpha$-terpineol $(15.6,11.3 \%)$ were the main constituents of hydrolates. $\beta$-Elemenone and germacrone were present in the amounts similar to that in respective essential oils. Only trace amounts of monoterpene hydrocarbons were present in the hydrolates. Surprisingly nonpolar selina-4(15),7(11)-diene and selina-3,7(11)-diene and other sesquiterpene hydrocarbons (which were present in both essential oils) were found in the hydrolate obtained from flowers. In this hydrolate hex-3-en-1-ol, benzaldehyde and benzyl alcohol were identified as minor components. These oxygenated compounds were not observed in essential oil due to high solubility in water. In previous research cis-hex-3-en-1-ol (9.0\%) and germacrone (13.5\%) were identified as the main constituents of $M$. gale hydrolate and small content of mono- and sesquiterpene alcohols [18]. It is obvious that pronounced differences in the composition of volatiles in essential oil and hydrolate occur, especially when essential oils consisted mainly of hydrocarbons. This is the case of the essential oils and hydrolates of two spruce and fir [19], Laurus nobilis [15] and many others. The amount of organic compounds in hydrolates depends on their content in the plant material however, it is limited by the solubility of individual compounds in water. The relative concentration of volatiles in both hydrolates was with good agreement with their solubility, measured at $25^{\circ} \mathrm{C}$ is the following: for 1,8 cineole $3500 \mathrm{mg} / \mathrm{L}$, for $\alpha$-terpineol $710 \mathrm{mg} / \mathrm{mL}$, and for $\alpha$-pinene $2.49 \mathrm{mg} / \mathrm{mL}$ [19].

\subsection{The Influence of Distillation Time on the Quality of Hydrolates}

In this research $1.9 \mathrm{~L}$ of total leaf hydrolate and $4 \mathrm{~L}$ of total flower hydrolate were produced from $1 \mathrm{~kg}$ of fresh plant material. These proportions were in agreement with indication that 1 to $5 \mathrm{~L}$ of hydrolate can be obtained from $1 \mathrm{~kg}$ of plant material, the amount varies depending on the particular plant [20]. It was proven that distillation time influenced both the content of volatile organic compounds in hydrolates and their percentage composition. As it is revealed in Table 2 and Table 3, showing the compounds present in amount of $1 \%$ or higher, longer time of distillation caused a reduction of volatile content in the hydrolate fraction. The fractions (438 to $92 \mathrm{mg} / \mathrm{L}$ ) and total hydrolate $(186 \mathrm{mg} / \mathrm{L})$ from the flowers were more abounded with the volatiles than the fractions from the leaves (142 to $44 \mathrm{mg} / \mathrm{L}$ and $66 \mathrm{mg} / \mathrm{L}$ ). This corresponded to the essential oil content in both plant parts. Previously Collin and Gagnon [18] produced $50 \mathrm{~kg}$ of hydrolate from $300 \mathrm{~kg}$ of $M$. gale aerial parts. The hydrolate contained $110 \mathrm{mg} / \mathrm{L}$ of volatile compounds. Taking into account the low volatile content in total leaf hydrolate it would be advised to mix only three first fractions. Such hydrolate would contain ca. $100 \mathrm{mg} / \mathrm{L}$ of volatiles and $1 \mathrm{~L}$ would be obtained from ca. $1 \mathrm{~kg}$ of plant material. 
A prolongation of distillation time caused an increase of the content of the compounds with higher mass (as sesquiterpenes) and opposite effect on low mass compounds. Good example of this phenomenon is the main component -1,8-cineole which represents oxygenated monoterpenes. In the first fraction of flower hydrolate it reached of $58.0 \%$, while in the fourth fraction only $22.0 \%$ of the total volatiles content. Similar effect was observed for leaf hydrolate - in the first fraction as much as $41.1 \%$ of all compound was 1,8-cineole, while in fifth fraction only $21.5 \%$ of this compound was present. The changes in the presence of higher mass compounds can be illustrated by germacrone, being one of the oxygenated sesquiterpenes. Germacrone content varied from $0.8 \%$ to $9.3 \%$ between the first and the last fraction of the flower hydrolate, and from $0.6 \%$ to $3.4 \%$ between those fractions of the leaf hydrolate.

Table 2. Composition of main volatile compounds of hydrolate fractions and total hydrolate of Myrica gale leaf

\begin{tabular}{|c|c|c|c|c|c|c|c|}
\hline \multirow{3}{*}{ No } & \multirow{3}{*}{ Compound } & \multicolumn{5}{|c|}{ Fraction No } & \multirow{2}{*}{$\begin{array}{c}\text { Total } \\
\text { hydrolate } \\
\mathbf{H}_{\text {leaf }} \\
\end{array}$} \\
\hline & & 1 & 2 & 3 & 4 & 5 & \\
\hline & & [\%] & {$[\%]$} & [\%] & [\%] & {$[\%]$} & [\%] \\
\hline 1 & Hex-3-en-1-ol & 1.4 & 0.3 & 0.1 & 0.5 & 1.2 & 1.1 \\
\hline 2 & Benzaldehyde & 0.6 & 1.2 & 0.5 & 0.8 & 1.5 & 0.5 \\
\hline 3 & 1,8-Cineole & 41.1 & 27.7 & 20.0 & 23.0 & 21.5 & 28.6 \\
\hline 4 & Linalool & 2.0 & 1.1 & 1.0 & 0.9 & 1.0 & 1.6 \\
\hline 5 & trans- $p$-Menth-2-en-1-ol & 1.0 & 0.6 & $\mathrm{t}$ & 0.3 & 0.4 & 1.0 \\
\hline 6 & $\delta$-Terpineol & 1.7 & 0.6 & 1.0 & 0.4 & 0.3 & 1.6 \\
\hline 7 & Borneol & 1.8 & 1.7 & 1.0 & 1.2 & 1.0 & 1.3 \\
\hline 8 & Terpinen-4-ol & 14.6 & 13.7 & 10.5 & 7.70 & 6.4 & 14.3 \\
\hline 9 & $\alpha$-Terpineol & 17.6 & 14.8 & 13.1 & 9.7 & 8.0 & 15.6 \\
\hline 10 & Benzyl acetate & 0.3 & 2.5 & 2.3 & 1.9 & 1.5 & 1.5 \\
\hline 11 & Citronellol & 1.9 & 1.2 & 1.5 & 1.1 & 0.9 & 1.7 \\
\hline 13 & (E)-Nerolidol & 0.5 & 1.2 & 1.8 & 1.5 & 1.8 & 1.0 \\
\hline 14 & Spathulenol & $\mathrm{t}$ & 0.7 & 1.3 & 1.0 & 0.1 & 0.1 \\
\hline 15 & $\beta$-Elemenone & 0.6 & 1.5 & 3.0 & 3.0 & 3.2 & 1.4 \\
\hline 16 & Isospathulenol & 0.7 & 1.8 & 3.0 & 3.5 & 5.0 & 2.5 \\
\hline 17 & 1-epi-Cubenol & 0.2 & 0.6 & 1.0 & 1.2 & 1.2 & 0.6 \\
\hline 18 & Germacrone & 0.6 & 1.5 & 2.8 & 3.2 & 3.4 & 1.7 \\
\hline 19 & Eudesm-7(11)-en-4a-ol & 0.2 & 0.6 & 1.3 & 1.4 & 1.6 & 0.7 \\
\hline 20 & Benzyl benzoate & - & 0.4 & 0.7 & 0.9 & 1.1 & 0.3 \\
\hline & Volatiles content $(\mathrm{mg} / \mathrm{L})$ & 142 & 81 & 73 & 53 & 44 & 66 \\
\hline
\end{tabular}

\subsection{Antimicrobial activity}

Antimicrobial activity of $M$. gale leaf essential oil and hydrolate was tested against both Gram-positive (S. aureus, E. faecalis) and Gram-negative bacteria (E. coli, P. aeruginosa), as well as fungi (C. albicans, $C$. glabarata). MIC and MBC values of essential oil are presented in Table 4. It was shown, that essential oil expressed the strongest activity against yeast achieving MIC at as low as $0.39 \%$. Leaf essential oil also inhibited the growth and viability of Gram-positive bacteria and E. coli showing the same activity against all of these microorganisms. 
Table 3. Composition of main volatile constituents of hydrolate fractions and total hydrolate of Myrica gale flower

\begin{tabular}{|c|c|c|c|c|c|c|}
\hline \multirow{3}{*}{ No } & \multirow{3}{*}{ Compound } & \multicolumn{4}{|c|}{ Fraction No } & \multirow{3}{*}{$\begin{array}{c}\text { Total } \\
\text { hydrolate } \\
\text { H }_{\text {flower }} \\
\\
{[\%]}\end{array}$} \\
\hline & & \multirow{2}{*}{$\begin{array}{c}1 \\
{[\%]}\end{array}$} & \multirow{2}{*}{$\begin{array}{c}2 \\
{[\%]}\end{array}$} & \multirow{2}{*}{$\begin{array}{c}3 \\
{[\%]}\end{array}$} & \multirow{2}{*}{$\begin{array}{c}4 \\
{[\%]}\end{array}$} & \\
\hline & & & & & & \\
\hline 1 & 1,8-Cineole & 58.0 & 31.7 & 32.4 & 22.0 & 44.2 \\
\hline 2 & trans-p-Menth-2-en-1-ol & 1.0 & 1.0 & 0.6 & 1.1 & 1.1 \\
\hline 3 & Camphene hydrate & 1.0 & 0.4 & 0.3 & - & 0.7 \\
\hline 4 & Borneol & 2.5 & 1.8 & 2.0 & 1.8 & 3.3 \\
\hline 5 & Terpinen-4-ol & 12.9 & 6.8 & 6.8 & 5.8 & 13.4 \\
\hline 6 & $\alpha$-Terpineol & 11.4 & 6.5 & 6.0 & 5.2 & 11.3 \\
\hline 7 & $\alpha$-Terpinyl acetate & 0.8 & 1.4 & 0.9 & 1.2 & 1.0 \\
\hline 8 & Selina-4(15),7(11)-diene & 1.0 & 2.7 & 1.5 & 1.1 & 1.3 \\
\hline 9 & Selina-3,7(11)-diene & 0.9 & 2.6 & 2.0 & 1.1 & 1.1 \\
\hline 10 & (E)-Nerolidol & 0.4 & 2.6 & 2.1 & 2.9 & 1.1 \\
\hline 11 & $\beta$-Elemenone & 0.7 & 7.8 & 10.7 & 12.3 & 3.7 \\
\hline 12 & Isospathulenol & 0.4 & 3.1 & 3.3 & 4.8 & 1.5 \\
\hline 13 & 1-epi-Cubenol & - & 0.9 & 1.0 & 1.3 & 0.4 \\
\hline \multirow[t]{2}{*}{14} & Germacrone & 0.8 & 6.3 & 9.7 & 9.3 & $\mathbf{3 . 0}$ \\
\hline & Volatiles content $(\mathrm{mg} / \mathrm{L})$ & 438 & 176 & 98 & 92 & 186 \\
\hline
\end{tabular}

However, there was no effect of $M$. gale leaf essential oil on $P$. aeruginosa in a whole range of tested concentrations. Similar results were obtained by Nakata et al. [21], who demonstrated antimicrobial activity of essential oil from cultivated M. gale var. tomentosa against Gram-positive bacteria including S. aureus and B. subtilis, as well as fungi such as Saccharomyces cerevisiae and $C$. albicans using disc diffusion method in agar. The strongest activity was observed against $B$. subtilis with the only one given MIC value at $61 \mathrm{ppm}(0,0061 \%)$, since the MIC for other microorganisms was above range of concentrations tested (> $1500 \mathrm{ppm})[21]$.

Table 4. Minimal inhibitory concentration (MIC) and minimal bactericidal/fungicidal concentration (MBC/MFC) of M. gale leaf essential oil

\begin{tabular}{lcc}
\hline \multicolumn{1}{c}{ Strain } & MIC [\%] & MBC/MFC [\%] \\
\hline S. aureus ATCC 29213 & 0.78 & 1.56 \\
S. aureus H9 (clinical MRSA) & 0.78 & 1.56 \\
E. faecalis ATCC 29212 & 0.78 & $>1.56$ \\
E. coli NCTC 8196 & 0.78 & 1.56 \\
P. aeruginosa ATCC 15442 & $>1.56$ & $>1.56$ \\
C. albicans ATCC 10231 & $\mathbf{0 . 3 9}$ & $\mathbf{0 . 7 8}$ \\
C. glabrata ATCC 90030 & $\mathbf{0 . 3 9}$ & $\mathbf{0 . 7 8}$ \\
\hline
\end{tabular}

Popovici et al. [22] showed inhibitory activity of the essential oils obtained from fruits of $M$. gale L. against a panel of foodborne fungi: Aspergillus flavus, Cladosporium cladosporioides and Penicillium expansum. A complete fungicidal effect was observed against $C$. cladosporioides at a concentration of $1000 \mathrm{ppm}$ ( $0.1 \%$ versus $0.78 \%$ for Candida sp. in our study). The authors suggest possible use of $M$. gale essential oils as an additive in food or cosmetics for their flavour, odour and conservative properties. Because of our results indicating on leaf essential oil activity against 
pathogenic bacteria and fungi, also disinfectants for usable industrial surfaces can be included to this list.

M. gale leaf hydrolate was less active in this respect, nevertheless, $75 \%$ solution of hydrolate resulted in a significant reduction in the viability of Gram-positive bacteria - in the range of 31-66\% (Table 5). Interestingly, tested hydrolate in contrast to essential oil was also active against $P$. aeruginosa reducing the viability of these bacteria by $30 \%$ and $63 \%$ when used at the concentration of $50 \%$ and $75 \%$, respectively. Moreover, there was no effect of leaf hydrolate against fungi in a whole range of concentrations tested. Taking into account the fact that the hydrolates are used in undiluted form it should be stated that the antibacterial potential of $M$. gale hydrolate is good despite the small amounts of organic volatile compounds $(66 \mathrm{mg} / \mathrm{L})$. It is known that the alcohols are amongst the most active antimicrobial essential oils' constituents beside phenols while the hydrocarbons reveal a poor activity [23]. Terpinen-4-ol and $\alpha$-terpineol, which were identified here in significant amounts in hydrolates' volatiles were among five out of twenty-one oxygenated monoterpenes showing the broadest spectrum of antibacterial efficacy measured by disc diffusion method, while 1,8-cineole appeared not active [24]. Hence, it is clear that these two alcohols were the key antimicrobial constituents of the hydrolates.

Table 5. Antimicrobial activity of $M$. gale leaf hydrolate measured as microbial viability in the presence of the preparation at different concentrations

\begin{tabular}{ccc}
\hline Strain & Hydrolate concentration [\%] & Viability [\%] \\
\hline \multirow{2}{*}{ S. aureus ATCC 29213 } & $\mathbf{7 5}$ & $\mathbf{6 9}$ \\
& 50 & 100 \\
S. aureus H9 (clinical MRSA) & 25 & 100 \\
\hline \multirow{2}{*}{ E. faecalis ATCC 29212 } & $\mathbf{7 5}$ & $\mathbf{6 8}$ \\
& 50 & 100 \\
& 25 & 100 \\
\hline \multirow{2}{*}{ E. coli NCTC 8196} & $\mathbf{7 5}$ & $\mathbf{3 4}$ \\
& $\mathbf{5 0}$ & $\mathbf{6 1}$ \\
P. aeruginosa ATCC 15442 & 25 & 100 \\
& $\mathbf{7 5}$ & $\mathbf{9 2}$ \\
& 50 & 100 \\
C. albicans ATCC 10231 & 25 & 100 \\
\hline \multirow{2}{*}{ C. glabrata ATCC 90030} & $\mathbf{7 5}$ & $\mathbf{3 7}$ \\
& $\mathbf{5 0}$ & $\mathbf{7 0}$ \\
\hline
\end{tabular}

Essential oils are natural products largely employed due to their beneficial properties [25]. MIC values of different essential oils lie in a broad range from $0.008 \%$ for tea tree oil to $2 \%$ for juniper oil [25]. In this respect both $M$. gale essential oils should be consider as middle active. Recently there is a growing interest in hydrolates that antimicrobial activity and potential were reviewed by D'Amato et al. [26]. Hydrolates can be used as face and air refreshers, cosmetic natural ingredients [16], fruit and vegetable sanitizers [27,28], and insecticides [29]. It can be concluded that M. gale leaves and flowers are valuable source of essential oils and hydrolates with fresh herbal smell and antimicrobial activity. These products can be used in wide variety of products. 


\section{Acknowledgments}

Authors acknowledge Aleksandra Budzyńska for technical help in performing of antimicrobial tests. The authors are grateful to Mr Robert Gwiazdecki and Mr Łukasz Bloch from Biofarm Połczyno, Poland for providing essential oils and hydrolates.

\section{ORCID}

Karolina Wawrzyńczak: 0000-0002-1017-7075

Beata Sadowska: 0000-0001-6383-3972

Marzena Więckowska-Szakiel: 0000-0003-2944-7327

Danuta Kalemba: 0000-0002-4018-5260

\section{References}

[1] K. Skene, J. Sprent, J. Raven and L. Herdman (2000). Myrica gale L., J. Ecol. 88, 1079-1094.

[2] M. Ciaciura and E. Stępień (2007). Distribution and actual state of Myrica gale L. Population on the Szczecin Coastland area, Acta Biol. 503, 54-61.

[3] K. Svoboda, A. Inglis, J. Hampson, B. Galambosi and Y. Asakawa (1998). Biomass production, essential oil yield and composition of Myrica gale L. harvested from wild populations in Scotland and Finland, Flavour Fragr. J. 13, 367-372.

[4] K. Wawrzyńczak, A. Jakiel and D. Kalemba (2019). Composition of leaf and flower essential oil of Myrica gale L., Biotechnol. Food Sci. 83, 87-96.

[5] R. Carlton, P. Waterman and A. Gray (1992). Variation of leaf gland volatile oil within a population of sweet gale (Myrica gale) (Myricaceae), Chemoecology 3, 45-54.

[6] M. Sylvestre, J. Legault, S. Lavoie and A. Pichette (2006). Investigation of leaf essential oil of Myrica gale L. from Quebec: purification and analysis of oxygenated fractions, J. Essent. Oil Res. 18, 38-41.

[7] F. Tavares, I. Abreu and R. Salema (1998). Regeneration of the actinorhizal plant Myrica gale L. from epicotyl explants, Plant Sci. 135, 203-210.

[8] Y. Liu, W. Wang, B. Fang, F. Ma, Q. Zheng, P. Deng, S. Zhao, M. Chen, G. Yang and G. He (2013). Anti-tumor effect of germacrone on human hepatoma cell lines through inducing G2/M cell cycle arrest and promoting apoptosis, Eur. J. Pharmacol. 698, 95-102.

[9] Q. Liao, Z. Qian, R. Liu, L. An and X. Chen (2013). Germacrone inhibits early stages of influenza virus infection, Antiviral Res. 100, 578-588.

[10] A. Maciąg and D. Kalemba (2015). Composition of rugosa rose (Rosa rugosa thunb.) hydrolate according to the time of distillation, Phytochem. Lett. 11, 373-377.

[11] R.P. Adams (2007). Identification of essential oil components by gas chromatography/ mass spectrometry, 4th ed. Allured Publishing Corporation, Carol Stream.

[12] A.E. Edris (2009). Identification and absolute quantification of the major water-soluble aroma components isolated from the hydrosols of some aromatic plants, J. Essent. Oil Bear. Pl. 12, 155-161.

[13] G. Collin, H. Gagnon, A. St-Gelais and M. Turcotte (2014). Composition of the essential oil and hydrosol of the roots of Ligusticum porteri, Am. J. Essent. Oils Nat. Prod. 1, 4-10.

[14] P. Di Leo Lira, D. Retta, E. Tkacik, J. Ringuelet, J.D. Coussio, C. van Baren and A.L. Bandoni (2009). Essential oil and by-products of distillation of bay leaves (Laurus nobilis L.) from Argentina, Ind. Crop. Prod. 30, 259-264.

[15] K. Śmigielski, R. Prusinowska, K. Krosowiak and M. Sikora (2013). Comparison of qualitative and quantitative chemical coposition of hydrolate and essential oils of lavender (Lavandula angustifolia), $J$. Essent. Oil Res. 25, 291-299.

[16] L. Gaoming, M. Peizhi, H. Minqing, W. Longhu, L. Xuesong and Z. Anyun (2016). Water soluble essential oil components of fresh flowers of Osmanthus fragrans Lour, J. Essent. Oil Res. 28, 177-184.

[17] N. Djabou, M. El Amine Dib, B. Tabti, J. Costa and A. Muselli (2014). Chemical composition and antioxidant activity of hydrosol extracts obtained by liquid-liquid extraction (LLE) of Daucus muricatus L., J. Essent. Oil Res. 26, 393-399.

[18] G. Collin and H. Gagnon (2015). Aromas from Quebec. IV. Chemical composition of the essential oil of Ledum groenlandicum: A review, Am. J. Essent. Oils Nat. Prod. 2, 6-11.

[19] F-X. Garneau, G. Collin, H. Gagnon and A. Pichette (2013). Chemical Composition of the hydrosol and the essential oil of three different species of the Pinaceae Family: Picea glauca (Moench) Voss., Picea mariana (Mill.) B.S.P., and Abies balsamea (L.) Mill, J. Essent. Oil Bear. Pl. 15, 227-236. 
[20] L. Price and S. Price (2004). Understanding hydrolats: the specific hydrosols for aromatherapy. Churchill Livingstone, England.

[21] M. Nakata, T. Myoda, Y. Wakita, T. Sato, I. Tanahashi, K. Toeda, T. Fujimori and M Nishizawa (2013). Volatile components of essential oil from cultivated Myrica gale var. tomentosa and its antioxidant and antimicrobial activities, J. Oleo Sci. 62, 755-762.

[22] S. Fandakli , N. Yayli, N. Kahriman, E. Uzunalioğlu, N. U. Çolak, S. Yıldırım and A. Yaşar (2019). The chemical composition of the essential oil, SPME and antimicrobial activity of Rhododendron caucasicum Pall, Rec.Nat.Prod. 13, 316-323.

[23] D. Kalemba and A. Kunicka (2003). Antibacterial and antifungal properties of essential oils, Curr. Med. Chem. 10, 813-829.

[24] R. Kotan, S. Kordali and A. Cakir (2007). Screening of antibacterial activities of twenty-one oxygenated monoterpenes, Z. Naturforsch. 62c, 507-513.

[25] F. Bakkali, S. Averbeck, D. Averbeck and M. Idaomar (2008). Biological effects of essential oils - A review, Food Chem. Toxicol. 46, 446-475.

[26] S. D'Amato, A. Serio, C. Chaves Lopez and A. Paparella (2018). Hydrosols: Biological activity and potential as antimicrobials for food applications, Food Contr. 86, 126-137.

[27] O. Sağdiç, I. Ozturk and F. Tornuk (2013). Inactivation of non-toxigenic and toxigenic Escherichia coli O157:H7 inoculated in minimally processed tomatoes and cucumbers: Utilization of hydrosols of Lamiaceae spices as natural food sanitizers, Food Cont. 30, 7-14.

[28] F. Tornuk, H. Cankurt, I. Ozturk, O.Sağdiç, O. Bayram and H. Yetim (2011). Efficacy of various plant hydrosols as natural food sanitizers in reducing Escherichia coli O157:H7 and Salmonella typhimurium on fresh cut carrots and apples, Int. J. Food Microbiol. 148, 30-35.

[29] N. Zekri, N. Handaq, A. El Caidi, T. Zair, and M.A. El Belghiti (2016). Insecticidal effect of Mentha pulegium L. and Mentha suaveolens Ehrh. hydrosols against a pest of citrus, Toxoptera aurantii (Aphididae), Res. Chem. Interm. 42, 1639-1649.

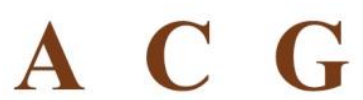

publications

(C) 2020 ACG Publications 